\title{
Research article \\ Cytotoxic and apoptotic activity of Canavalia seed extract in HT-29 human colon carcinoma cells
}

\author{
Geetha Suvarna $^{1}$, Ashwini Prabhu ${ }^{2}$, Katheeja Muhseena N. ${ }^{2}$, Bhagya B. Sharma ${ }^{1}$ \\ ${ }^{1}$ Centre for Environmental Studies, ${ }^{2}$ Yenepoya Research Centre, Yenepoya (Deemed to be University), Mangalore-575018, \\ Karnataka, India
}

(Received: February $2021 \quad$ Revised: March $2021 \quad$ Accepted: March 2021)

Corresponding author: Bhagya B. Sharma. Email: bagyabs@gmail.com

\begin{abstract}
Introduction and Aim: Concanavalin the lectin from Canavalia spp. share high structural similarity among the same taxon and exhibit wide range of biological functions. The antiproliferative activity of lectins ConA $(C$. ensiformis), ConC (C. cathartica), ConG (C. gladiata) and ConM (C. rosea) were studied in human colon carcinoma.

Materials and Methods: Human colon carcinoma HT-29 cells and human normal kidney HEK293T cells were examined. The cytotoxicity was evaluated by MTT assay. Cell apoptosis was analyzed by AO-EB (acridine orangeethidium bromide dual staining) method. Cell cycle was investigated by flow cytometry (RNase-propidium iodidebased flow cytometry). The expression of cell signaling genes was analyzed by qRT-PCR.

Results: All concanavalins significantly inhibited the proliferation of HT-29 cells in dose-dependent manner ( $\mathrm{IC}_{50}$ values were ConG-10.45, ConA-14.86, ConC-33.34 and ConM-48.98 $\mu \mathrm{g} / \mathrm{mL}$ respectively). ConA and ConG induced apoptotic morphology in HT-29 cells without affecting HEK293T cells. Similarly, both lectins increased the sub- $\mathrm{G}_{0} / \mathrm{G}_{1}$ proportions in HT-29 cells dose-dependently. ConG showed down-regulation of AKT1, ERK1/2 and mutant $\mathrm{p} 53$ in HT-29 cells.
\end{abstract}

Conclusion: Concanavalin extract is shown to possess cytotoxic effect through inducing apoptosis, especially causing cell cycle arrest at $\mathrm{G}_{0} / \mathrm{G}_{1}$ phase in HT-29 cells.

Keywords: Canavalia seed extracts; HT-29 cell lines; cytotoxicity; apoptosis; cell cycle.

\section{INTRODUCTION}

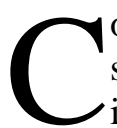

oncanavalin (Con), a lectin from Canavalia spp. exhibit various biological functions due to its sugar binding property in reversible manner. They are homo-tetramers with each monomer consisting of a carbohydrate recognition domain (CRD), two metal binding sites and a hydrophobic site (1). Canavalia lectins share high similarity in nucleotide and protein homology. However, few positional changes in amino acids residues results in differential biological functions (2). Concanavalin show high specificity towards mannose/glucose sugars as demonstrated by hemagglutination inhibition assay (3). These amino acid changes and interactions influence binding of concanavalin to cell surface receptors. The concanavalin extracted from C. ensiformis (ConA) is the widely studied lectin exhibiting various functions like hemagglutination, mitogenicity, antitumor, insecticidal and antimicrobial activity (see 3 ). ConA has been reported to induce cell death in different human cancer cell lines through apoptosis and autophagy. Induction of apoptosis is characterized by cytotoxicity, nuclear condensation, DNA fragmentation and membrane blebbing. Apoptotic efficacy of ConA is reported in different cell lines (46), while concanavalins from $C$. gladiata (ConG), $C$. cathartica $(\mathrm{ConC})$ and $C$. rosea (ConM) are less explored $(1,3)$.

Glycans present on the tumor cell surface play an integral role in the cancer cell proliferation. A modified glycosylation patterns is observed on the cancer cells, which results in substantial change in specific metabolic processes (7). Lectins are cell recognition molecules which can interact with carbohydrate moieties with high affinity and specificity. Due to their selective specificity towards altered glycans present on the tumor cell surfaces, they can be exploited as efficient anticancer lead molecules and cancer biomarker (7). According to global cancer statistics (2018), colorectal cancer (CRC) is the most commonly diagnosed cancer with incidence rate of $\sim 1.85$ million and 880,792 deaths (8). The present study evaluated the cytotoxicity and apoptotic efficacy of semi-purified concanavalin extracts on human colon carcinoma HT-29 cells.

\section{MATERIALS AND METHODS}

\section{Chemicals}

Antibiotic-antimycotic solution, Dulbecco's modified eagle medium (DMEM), fetal bovine serum (FBS), trypsin-EDTA solution and 3-(4,5-dimethylthiazol-2yl)-2,5-diphenyltetrazolium bromide (MTT) were bought from Himedia, India. Acridine orange, 
Dimethyl sulfoxide (DMSO) and ethidium bromide were acquired from Merck, India. Primers for qRTPCR in lyophilized form were procured from BioServe Biotechnologies Ltd. (Hyderabad, India). Verso cDNA synthesis kit and SYBR ${ }^{\circledR}$ Green master mix were from Thermo Scientific, USA.

\section{Cell culture}

Human colon carcinoma HT-29 and normal HEK293T cell lines were procured from National Centre for Cell Sciences (NCCS), Pune, India. Cells were cultured in Dulbecco's Modified Eagle Medium (DMEM) comprising 10\% fetal bovine serum and $1 \%$ antibiotic-antimycotic solution $(10000 \mathrm{U}$ penicillin, $10 \mathrm{mg}$ streptomycin and $25 \mu \mathrm{g}$ amphotericin B). The cultures were maintained at $37^{\circ} \mathrm{C}$ in an incubator with $5 \% \mathrm{CO}_{2}$ and humidified atmosphere. Cells were subcultured upon attaining $70 \%$ confluence and used for various experiments.

\section{Canavalia seed collection}

Seeds of C. cathartica, C. ensiformis, C. gladiata and C. rosea were collected from Kallapu $\left(12^{\circ} 49^{\prime} 47.3^{\prime \prime} \mathrm{N}\right.$,


Adyanadka $\left(12^{\circ} 69^{\prime} 54.2^{\prime \prime} \mathrm{N}, \quad 75^{\circ} 10^{\prime} 77.5^{\prime \prime} \mathrm{E}\right)$ and Tannirbavi $\left(12^{\circ} 88^{\prime} 67.7^{\prime \prime} \mathrm{N}, 7^{\circ} 81 ' 51.7^{\prime \prime} \mathrm{E}\right)$ region of Dakshina Kannada District, Karnataka, India. All plant samples were authenticated by a taxonomist and voucher specimens deposited at the herbarium.

\section{Fractional precipitation of the concanavalin with ammonium sulfate}

Crude extract was prepared by homogenizing seed cotyledon powder (10\%) in $0.15 \mathrm{M} \mathrm{NaCl}$ and subjected to salting-out using ammonium sulfate (9). The extract was precipitated by ammonium sulfate at different saturation levels $(0-20 \%, 20-40 \%, 40-60 \%$, $60-80 \%$, 80-100\%). Protein concentration was assessed by Lowry's method (10) and specific activity was determined by hemagglutination assay which is a simple and sensitive method for quantification of lectins (11). Protein precipitate with high specific activity was dialysed against distilled water, dried and dissolved in phosphate buffered saline. The resultant semi-purified concanavalin extracts were used to perform cytotoxicity assays.

\section{Ethical clearance}

The hemagglutination assay was performed in human erythrocytes. Peripheral blood $(\sim 3 \mathrm{~mL})$ was collected from healthy volunteer with the approval from institutional ethical committee (YUEC protocol no2018/052).

\section{MTT assay}

The cell viability was assessed by MTT assay (12). HT-29 cells were seeded into 96-well plates at $5 \times$ $10^{3}$ cells/well. The different concentrations $(12.5,25$, $50,100,200,400$ and $800 \mu \mathrm{g} / \mathrm{mL}$ ) of concanavalin extract was added and incubated for $24 \mathrm{~h}$ at $37^{\circ} \mathrm{C}$.
Untreated cells were used as negative control. The MTT reagent $(1 \mathrm{mg} / \mathrm{mL})$ was added and further incubated for $4 \mathrm{~h}$ at $37^{\circ} \mathrm{C}$. The MTT formazan crystals formed were solubilized in $100 \mu \mathrm{L}$ of DMSO and absorbance was recorded at $570 \mathrm{~nm}$ in multimode microplate reader (FluoSTAR Omega, BMG Labtech, Germany). Percentage inhibition was determined using the formula,

Percentage growth inhibition $=[$ (Mean absorbance in control well - Mean absorbance in test well)]/ Mean absorbance in control well) $\times 100$.

Dose response curve was plotted and $\mathrm{IC}_{50}$ value was calculated.

\section{Detection of Apoptosis}

\section{AO-EB dual staining}

Acridine Orange/Ethidium Bromide (AO/EB) dual staining was applied for determining the morphological changes in cells (13). The HT-29 cells were seeded in 12-well plate at a density of $2 \times 10^{4}$ cells/well and incubated with $\mathrm{IC}_{50}, 1 / 2 \mathrm{IC}_{50}$ and $1 / 4 \mathrm{IC}_{50}$ concentrations of ConA and ConG extracts in triplicates at $37^{\circ} \mathrm{C}$ for $24 \mathrm{~h}$. Untreated cells were used as control. The cells were fixed with chilled methanol for $30 \mathrm{~min}$ and stained with $\mathrm{AO}(2 \mu \mathrm{g} / \mathrm{mL})$ and $\mathrm{EB}(2$ $\mu \mathrm{g} / \mathrm{mL}$ ) at $37^{\circ} \mathrm{C}$ for $15 \mathrm{~min}$. The stained cells were washed with PBS, observed, and photographed under fluorescence cell imager (ZOE, Bio-Rad, USA) with B-2A filter at $20 \mathrm{X}$ magnification. The apoptotic cells were identified by cellular morphology and fluorescence emission. The cells emitting green fluorescence with intact nuclear structure were considered as viable cells, whereas early apoptotic cells fluoresce yellow-green and late apoptotic cells fluoresce orange red with condensed chromatin.

\section{Flow cytometric assay}

Effect on cell division was assessed by flow cytometric assay. The HT-29 cells $\left(2 \times 10^{4}\right.$ cells/well) were seeded into 12 -well plate and incubated with $\mathrm{IC}_{50}$ and $1 / 2 \mathrm{IC}_{50}$ concentrations of extracts of ConA and ConG at $37^{\circ} \mathrm{C}$ for $24 \mathrm{~h}$. Untreated cells were used as control. Cells were harvested and suspended in staining solution containing RNase A $(0.1 \mathrm{mg} / \mathrm{mL})$ and propidium iodide $(5 \mu \mathrm{g} / \mathrm{mL})$. Stained cells were analyzed for cellular DNA (Deoxyribonucleic acid) content by flow cytometer (Guava EasyCyte, Merck Millipore, USA). The data was analyzed by flowing software v2.5.1 (14) and the proportion of cells in three major phases of cell cycle $\left(\mathrm{G}_{0} / \mathrm{G}_{1}, \quad \mathrm{~S}\right.$ and $\left.\mathrm{G}_{2} / \mathrm{M}\right)$ and apoptotic cells with fractional DNA content (sub$\mathrm{G}_{0} / \mathrm{G}_{1}$ phase) was determined.

\section{qRT-PCR}

Relative gene expression of genes influencing cell cycle was quantified by quantitative reverse transcription polymerase chain reaction (qRT-PCR) 
method. The genes examined for their expression are p53, AKT1 and ERK1/2 involved in cell signaling regulation and proliferation. A total of $2 \times 10^{4}$ HT-29 cells were plated in a $60 \mathrm{~mm}$ culture dish and incubated for $24 \mathrm{~h}$ at $37^{\circ} \mathrm{C}$ in $5 \% \mathrm{CO}_{2}$. The cells were treated with $\mathrm{IC}_{50}, 1 / 2 \mathrm{IC}_{50}$ and $1 / 4 \mathrm{IC}_{50}$ concentration of ConG extract for $24 \mathrm{~h}$. Untreated cells were used as control. The total RNA was isolated from treated cells and control by modified Trizol extraction method (15) and quantified in a Nanospectrophotometer (Titertek-Berthold, Germany). For each treatment group, approximately $500 \mathrm{ng}$ of RNA was used to synthesize cDNA (Agilent Sure Cycler 8800 ) using Verso cDNA synthesis kit (Thermo Scientific) as per manufacturer's instructions. The primer sequence used is shown in Table 1. The qRTPCR experiment was performed using SYBR ${ }^{\circledR}$ Green master mix in a real-time thermal cycler (Bio-Rad CFX96, Singapore) with following conditions: initial denaturation at $95^{\circ} \mathrm{C}$ for $3 \mathrm{~min}$ and amplification of 40 cycles $\left(95^{\circ} \mathrm{C}\right.$ for $15 \mathrm{~s}$ for denaturation, $57.5^{\circ} \mathrm{C}$ for $1 \mathrm{~min}$ for annealing and $65^{\circ} \mathrm{C}$ for $5 \mathrm{~s}$ for extension). The $2^{-\Delta \Delta \mathrm{Ct}}$ method was used to determine the effect of the experimental treatment and to calculate relative changes in mRNA expression of target gene normalized to $\beta$-actin and average fold-change for each gene was determined compared to untreated cells (16). The fold change value less than 1 implies decrease in gene expression.

Table 1: Primer sequences for qRT-PCR

\begin{tabular}{|c|c|c|}
\hline Gene & Forward primer & Reverse primer \\
\hline AKT1 & TGGACTACCTGCACTCGGAGAA & GTGCCGCAAAAGGTCTTCATGG \\
\hline ERK1 & TGGCAAGCACTACCTGGATCAG & GCAGAGACTGTAGGTAGTTTCGG \\
\hline ERK2 & ACACCAACCTCTCGTACATCGG & TGGCAGTAGGTCTGGTGCTCAA \\
\hline $\mathbf{p 5 3}$ & CCTCAGCATCTTATCCGAGTGG & TGGATGGTGGTACAGTCAGAGC \\
\hline $\boldsymbol{\beta}$-actin & CACCATTGGCAATGAGCGGTTC & AGGTCTTTGCGGATGTCCACGT \\
\hline
\end{tabular}

AKT is serine/threonine kinase, ERK is extracellular signal-regulated kinase, p53 is tumor suppressor protein, $\beta$ actin is internal control.

\section{Statistical analysis}

The data were analyzed using Statistical Package for Social Sciences (SPSS) software version 23.0. The data are expressed as mean $\pm \mathrm{SD}$ from three replicates per treatment. Treatment groups were compared to control and analysed by one-way ANOVA followed by Tuckey's post-hoc test. The level of significance was set at $\mathrm{p}<0.05$.

\section{RESULTS}

\section{Concanavalin precipitate}

Crude extract from Canavalia seeds were purified by using ammonium sulfate precipitation at different saturation levels $(0-20 \%, 20-40 \%, 40-60 \%, 60-80 \%$, $80-100 \%)$. The protein concentration was quantified and hemagglutination activity was determined for each fraction. The specific activity evaluated using total protein and hemagglutination unit was found to be higher in 40-60\% precipitated fraction. The ConA, ConC, ConG and ConM fraction respectively showed $2.19,1.40,2.14$ and 1.40-fold increase in specific activity compared to crude extract. Desalting of 40$60 \%$ precipitated fraction was performed by dialysis in distilled water. The purity of final product was 1.86 (ConA), 1.62 (ConC), 2.43 (ConG) and 1.50fold higher than crude extract (Table 2).

Table 2: Total protein concentration and specific activity of concanavalin extract

\begin{tabular}{|c|c|c|c|c|c|}
\hline Concanavalin & Fractions & $\begin{array}{c}\text { Total } \\
\text { protein } \\
(\mathrm{mg})^{\mathrm{a}}\end{array}$ & $\begin{array}{c}\text { Specific } \\
\text { activity } \\
(\text { HU/mg) }\end{array}$ & $\begin{array}{l}\text { Purification } \\
\text { fold }^{c}\end{array}$ & $\begin{array}{l}\text { Recovery of } \\
\text { activity }(\%)^{d}\end{array}$ \\
\hline \multirow[t]{3}{*}{ Con $\mathrm{A}$} & Crude extract & 6667.83 & 1036.62 & 1.00 & 100.00 \\
\hline & $\begin{array}{l}\text { 40-60\% Ammonium } \\
\text { sulphate precipitate }\end{array}$ & 1355.03 & 2267.11 & 2.19 & 44.44 \\
\hline & Dialysate & 1225.70 & 1931.96 & 1.86 & 34.26 \\
\hline \multirow[t]{3}{*}{ ConC } & Crude extract & 7831.23 & 7159.03 & 1.00 & 100.00 \\
\hline & $\begin{array}{l}\text { 40-60\% Ammonium } \\
\text { sulphate precipitate }\end{array}$ & 2603.40 & 10029.95 & 1.40 & 46.58 \\
\hline & Dialysate & 1859.56 & 11564.01 & 1.62 & 38.36 \\
\hline \multirow[t]{3}{*}{ ConG } & Crude extract & 6251.14 & 8927.65 & 1.00 & 100.00 \\
\hline & $\begin{array}{l}\text { 40-60\% Ammonium } \\
\text { sulphate precipitate }\end{array}$ & 1337.47 & 19140.56 & 2.14 & 45.87 \\
\hline & Dialysate & 944.13 & 21692.00 & 2.43 & 36.70 \\
\hline \multirow[t]{3}{*}{ ConM } & Crude extract & 7705.76 & 7242.37 & 1.00 & 100.00 \\
\hline & $\begin{array}{l}\text { 40-60\% Ammonium } \\
\text { sulphate precipitate }\end{array}$ & 2518.41 & 10165.16 & 1.40 & 45.87 \\
\hline & Dialysate & 1884.59 & 10867.07 & 1.50 & 36.70 \\
\hline
\end{tabular}




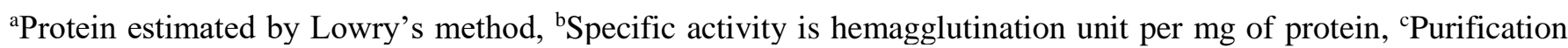
fold is the fold- increase in specific activity compared to crude extract, ${ }^{\mathrm{d}}$ Recovery of activity (\%) is the measure of agglutination activity retained compared to crude extract.

\section{Cytotoxic effects}

All concanavalins have cytotoxic effects in HT-29 cells. Potent inhibitory effects were observed in a dose-dependent manner up to $100 \mu \mathrm{g} / \mathrm{mL}$ with significant $(\mathrm{p}<0.001)$ percentage viability at different concentrations (figure 1 ). The $\mathrm{IC}_{50}$ values determined from the concentration-response curve was in the following order - ConG $(10.45 \mu \mathrm{g} / \mathrm{mL})>$ ConA $(14.86 \mu \mathrm{g} / \mathrm{mL})>\operatorname{ConC}(33.34 \mu \mathrm{g} / \mathrm{mL})>\operatorname{ConM}$
(48.98 $\mu \mathrm{g} / \mathrm{mL})$. Higher cytotoxicity was seen in ConA and ConG compared to ConC and ConM. However, the extracts did not show significant toxicity in normal HEK293T cell line (17). The results indicate ConA and ConG extracts have more potent growth inhibitory activity towards HT-29 cells than other concanavalins and hence were further evaluated for their apoptotic efficacy.

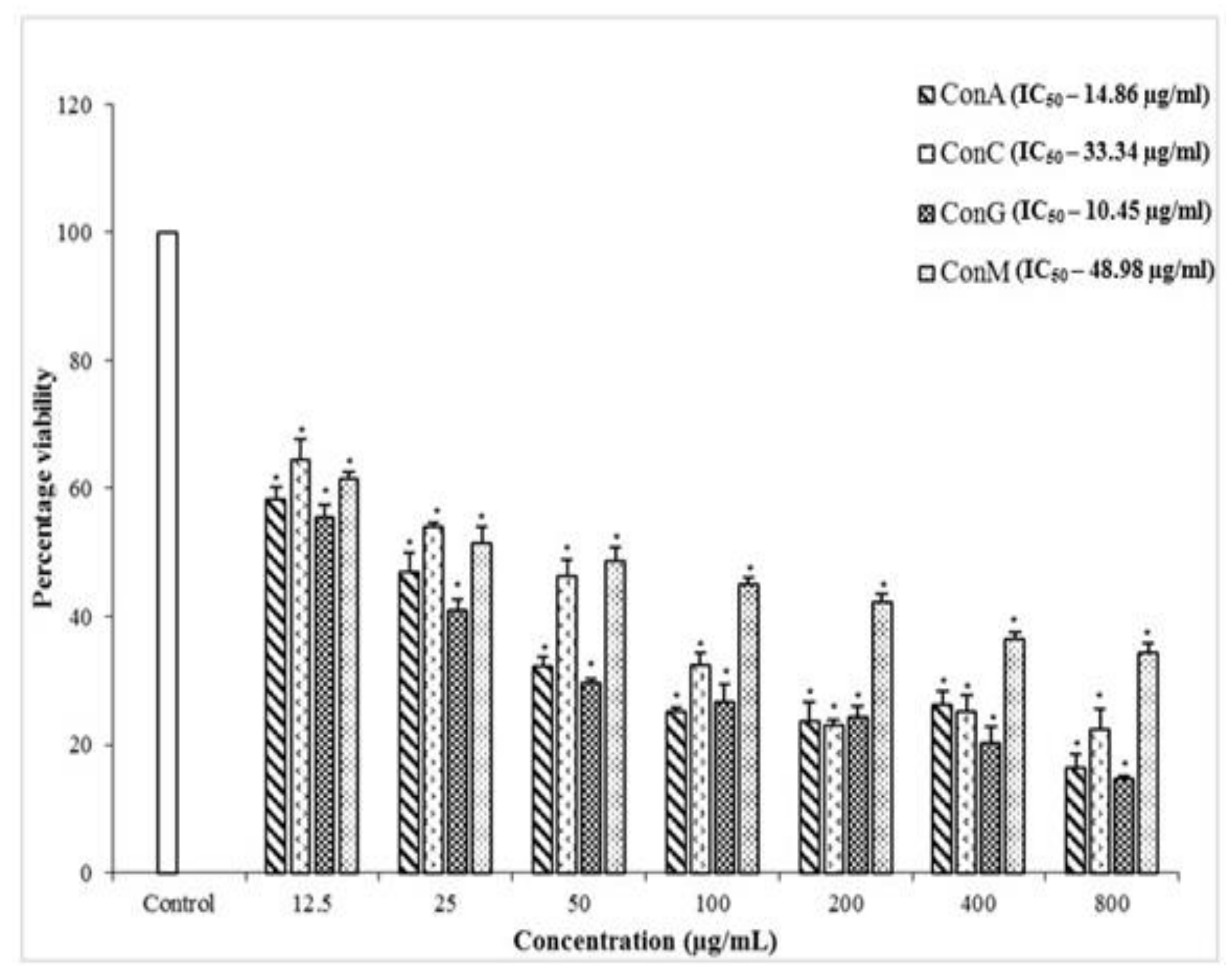

Fig. 1: Effect of concanavalins on the proliferation of HT-29 cells

Cell viability of HT-29 cells was determined by MTT assay after $24 \mathrm{~h}$ treatment with different concentrations of lectin extracts. Data are presented as the Mean \pm SD of three replicates. Percentage viability in treatment group statistically differed from control group $(* \mathrm{p}<0.001$; One - Way ANOVA)

\section{Observation of cellular morphology}

The results of AO-EB staining show notable apoptotic morphological changes such as chromatin condensation, DNA fragmentation and apoptotic bodies (figure 2). AO-EB differential staining demonstrated late apoptotic cells with orange fluorescence at higher concentrations and early apoptotic cells displayed yellowish green fluorescence at lower concentrations. However, ConA and ConG did not result in apoptotic morphology in control group. The results indicated that both ConA and ConG extract selectively induced HT-29 apoptosis. 


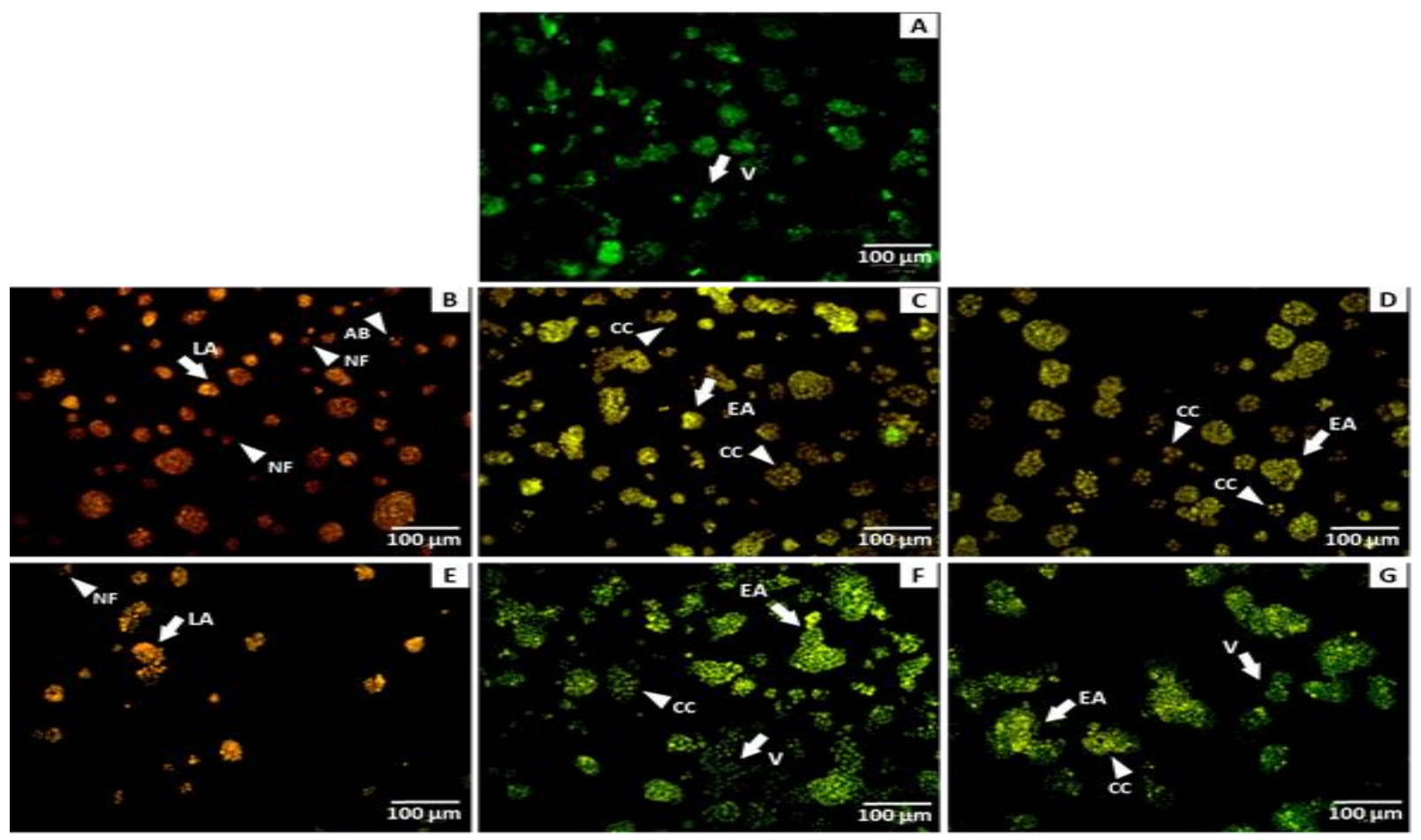

Fig. 2: Morphologic observations of HT-29 cells treated with ConA and ConG

Control cells (A); Cells treated with ConA (IC 50 (B), 1/2 $\mathrm{IC}_{50}$ (C), 1/4 IC $\mathrm{IC}_{50}$ (D)) and ConG (IC 50 (E), 1/2 IC $\mathrm{IC}_{50}(\mathrm{~F}), 1 / 4$ $\mathrm{IC}_{50}(\mathrm{G})$ ). Images of cells stained with acridine orange-ethidium bromide was captured by overlapping green and red channels with a scale bar of $100 \mu \mathrm{m}$. Labels: V-viable cell, EA-early apoptosis, LA-late apoptosis, CCchromatin condensation, NF-nuclear fragmentation, AB-apoptotic body

\section{Cell cycle analysis}

As demonstrated in figure 3, the extracts of ConA and ConG (Figure 3) markedly increased HT-29 cell sub- $\mathrm{G}_{0} / \mathrm{G}_{1}$ proportions in a dose-dependent manner, indicating that both extracts induced apoptosis in HT29 cells. Moreover, both lectins decreased the proliferation phases of cell cycle in $\mathrm{G}_{0} / \mathrm{G}_{1}, \mathrm{~S}$ and $\mathrm{G}_{2} / \mathrm{M}$.



Fig. 3: Effect of ConA and ConG on cell cycle distribution in HT-29 cells

Histograms of the DNA content of each phase of the cell cycle in untreated HT-29 cells (A); Cells treated with ConA (IC ${ }_{50}(\mathrm{~B})$, $\left.1 / 2 \mathrm{IC}_{50}(\mathrm{C})\right)$ and $\mathrm{ConG}\left(\mathrm{IC}_{50}(\mathrm{D}), 1 / 2 \mathrm{IC}_{50}(\mathrm{E})\right)$. 


\section{Analysis of apoptosis-related genes}

The qRT-PCR analysis shows relative mRNA decrease in expression of AKT1, ERK1/2 and mutant p53 genes. The data demonstrated that treatment of HT-29 cells with ConG resulted in down-regulation of these genes in a dose-dependent manner (figure 4).

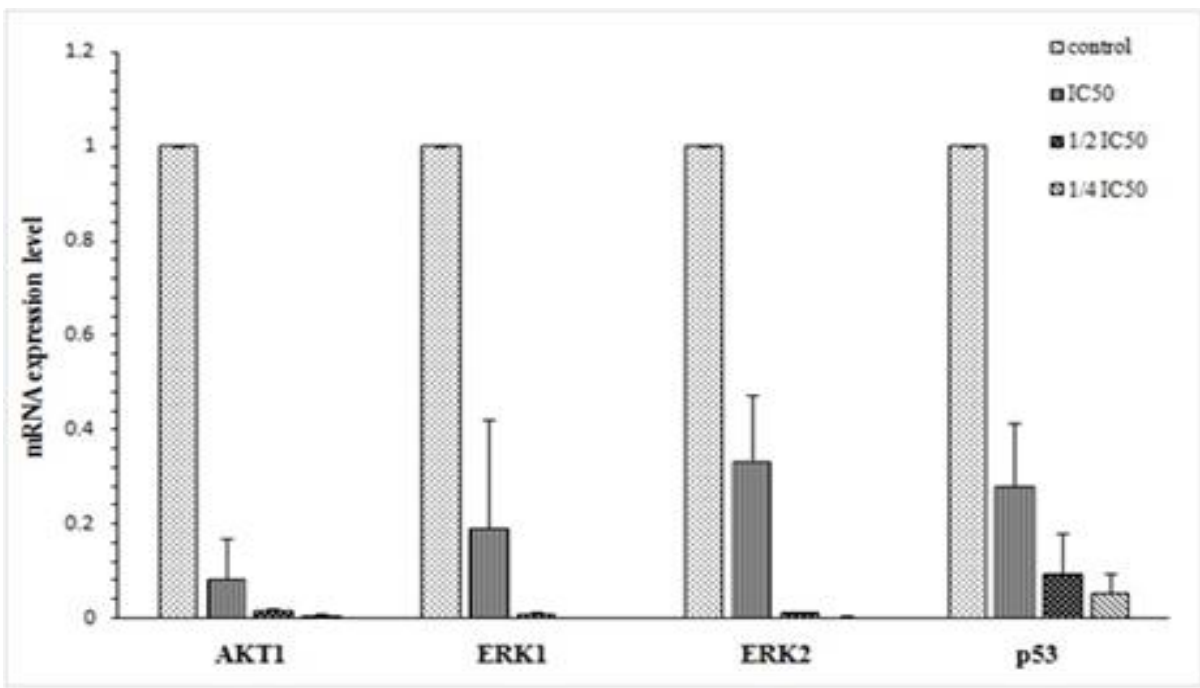

Fig. 4: Effect of ConG on expression of apoptosis-related genes in HT-29 cells

Fold change in gene expression was determined by qRT-PCR. Results are represented as Mean \pm SD of three replicates

\section{DISCUSSION}

Legume lectins are extensively studied for antitumor activity that induce cytotoxicity, apoptosis and inhibit the growth of cancer cells $(4,5)$. Concanavalins from Canavalia spp. is a member of legume lectin family and share high genetic similarity $(1,2)$. This similarity is replicated in primary protein structure with conserved carbohydrate recognition domain (CRD), metal binding site and hydrophobic site (1). However, variation in configuration of these functional sites was observed in quaternary structures of concanavalins (2).

ConA is the first concanavalin to be isolated and is widely studied for its structure and function. However, there are few reports on biological activities of other concanavalins. These homologous proteins are shown to exhibit distinct biological activities despite high similarity in their structural configuration (1-3). ConA is reported to exhibit more specificity towards D-mannose as per reports $(1,3)$. ConC, ConG and ConM also showed similar specificity but difference was observed in binding affinity (unpublished data) which might influence its functional properties. Lectins induce apoptosis by binding to glycoproteins on the cell surface (7). The sugar affinity is seen to have positive correlation for antiproliferative activity in ConA (6). In this study, ConA, ConC, ConG and ConM were isolated from four accessions of Canavalia spp. and studied for their antiproliferative activity in human colon carcinoma HT-29 cells.

Various methods of concanavalin purification have been reported mainly affinity chromatography using different columns (1). In the present study, a modified protocol (9) for extraction of concanavalin from seeds of Canavalia by salting-out technique is followed. The presence of concanavalin in the extract was assessed by hemagglutination assay (11). The lectin extracts with higher specific activity was selected for antiproliferative activity analysis.

The concanavalins showed significant cytotoxic effect with ConA and ConG being more toxic than ConC and ConM. This distinct activity exhibited by these homologous proteins may be due to variation in volume and configuration of $\mathrm{CRD}$ and $\mathrm{pH}$-dependent oligomerization state $(1,2)$. In addition, these lectins did not cause any toxicity in normal kidney HEK293T cells (17). Such difference in binding affinity is due to altered glycosylation pattern on the cancer cell surface (7). Breast cancer cell lines are shown to over-express high mannose glycans compared to normal epithelial cell line (18). The selective toxicity displayed by mannose-specific concanavalins in the present study supports this observation. ConA is reported to induce cell death in leukemic (MOLT-4 and HL-60), melanoma (A375), breast cancer (MCF7) and cervical cancer (HeLa) cells $(4-6,19)$. ConG showed inhibition of L1210 leukemia and B16 melanoma cell lines $(20,21)$.

Apoptosis is a cellular mechanism which gets rid of damaged cells and is important for the survival of multicellular organisms. It is characterized by chromatin condensation, DNA fragmentation and formation of apoptotic bodies (13). The observation of these morphological characteristics in AO-EB stained HT-29 cells confirms apoptotic efficacy of ConA and ConG extracts. Supporting this data, ConA is shown to induce mitochondrial apoptosis, mitochondrial autophagy, increased ROS production, increased caspase- $3,-8$ and -9 activity, up-regulation of pro-apoptotic proteins (Bax, Bid), down-regulation 
of anti-apoptotic proteins (Bcl-2 and Bcl-XL), downregulation of cell cycle proteins (CDK1, CDK2; 4-6).

Further, the cells in different cell cycle phases was measured to evaluate the effect of concanavalins on regulation of cell cycle dynamics. The present study showed accumulation of sub- $\mathrm{G}_{0} / \mathrm{G}_{1}$ proportion with decrease in cell proportion at proliferation phases $\left(\mathrm{G}_{0} / \mathrm{G}_{1}, \mathrm{~S}\right.$ and $\left.\mathrm{G}_{2} / \mathrm{M}\right)$. The sub- $\mathrm{G}_{0} / \mathrm{G}_{1}$ peak in flow cytometric data is indicative of DNA fragmentation, which is one of the hallmarks of apoptosis (22). Supporting the present data, ConA and $\mathrm{ConBr}$ induced accumulation of sub- $\mathrm{G}_{0} / \mathrm{G}_{1}$ proportion in human leukemic MOLT-4 and HL-60 cells (5). The sub- $\mathrm{G}_{0} / \mathrm{G}_{1}$ proportion increased in dose-dependent manner in ConA treated MCF-7 cells (4) while in HeLa cells, time-dependent increase was observed (19). In this study, we report ConG induces apoptosis in human colon carcinoma HT-29 cells.

Colorectal cancer progression is associated with deregulation of signaling pathways promoting proliferation and inducing metastasis (23). The AKT, ERK, p53 and other signaling pathways are critical for cellular functions and are commonly deregulated in cancers $(23,24)$. The $\mathrm{p} 53$ is a major tumor suppressor protein, which plays an important role in cell survival under genotoxic stress. The p53 gene is mutated (mutant p53) in approximately $50 \%$ of human cancer cell types including HT-29 cells. In other malignant cells, functional inactivation of wild type p53 is observed (24). The downregulation of mutant p53 and up-regulation of wild-type p53 is related to suppression malignant properties of cancer cells (24). The serine/threonine kinase AKT (or also known as protein kinase B) regulates different cellular functions such as proliferation, apoptosis, cell migration and glucose uptake. Among the three isoforms (AKT1, AKT2 and AKT3), AKT1 plays a critical role in cancer physiology specifically cell invasion and migration in different cancer types (23). The ERK (extracellular signal-regulated kinase) is a member of mitogen activated protein kinase family (MAPK) and are crucial for several physiological processes. Hence, downregulating the expression of ERK by intermediate molecules is considered to be a promising option in achieving efficient cancer therapy (23). ConA is shown to inhibit AKT expression in p53-null cells (25). The ConA induced apoptosis via down-regulation of ERK proteins in MCF-7 cells (4). ConBr decreased phosphorylation of ERK1/2 and AKT in C6 glioma cells (26). In this study, extract of ConG induced apoptosis via downregulation of p53, AKT1 and ERK1/2 in HT-29 cells which is comparable to the results of other concanavalins.

\section{CONCLUSION}

This study demonstrates that semi-purified concanavalin induces cell death and apoptosis in colon carcinoma HT-29 cells. ConA and ConG increased sub- $\mathrm{G}_{0} / \mathrm{G}_{1}$ proportions inducing apoptotic cell death. The apoptotic cell death induced by ConG extract is by down-regulation of p53, AKT1 and ERK1/2 pathways. From the results, it is noteworthy that ConG was more effective than other lectins. The limitation of the current study is that a crude extract of lectin was used for the analysis. Further studies with purified lectins would help understand the structure-function relationship in concanavalins.

\section{ACKNOWLEDGEMENT}

First author acknowledges Yenepoya (Deemed to be University) for providing the Junior Research Fellowship and necessary facilities for carrying out this work.

\section{CONFLICT OF INTEREST}

Authors declare that they have no conflicts of interest.

\section{REFERENCES}

1. Cavada, B. S., Pinto-Junior, V. R., Osterne, V. J., Nascimento, K. S. ConA-like lectins: high similarity proteins as models to study structure/biological activities relationships. Int $\mathbf{J}$ Mol Sci. 2019; 20(1): 30. doi: 10.3390/ijms20010030

2. Suvarna, G., Sharma, B. B. An analogy of Canavalia lectins by molecular phylogenetic characterization. J Proteins Proteom. 2020; 11(3): 193-203. doi:10.1007/s42485-02000041-y

3. Suvarna, G., Sharma, B. B. Concanavalin-A potential glycoprotein. J Proteins Proteom. 2018; 9(2): 77-90.

4. Shi, Z., Chen, J., Li, C. Y., An, N., Wang, Z. J., Yang, S. L., et al., Antitumor effects of concanavalin A and Sophora flavescens lectin in vitro and in vivo. Acta Pharmacologica Sinica. 2014; 35(2): 248-256. doi:10.1038/aps.2013.151

5. Faheina-Martins, G. V., da Silveira, A. L., Cavalcanti, B. C., Ramos, M. V., Moraes, M. O., Pessoa, C., et al., Antiproliferative effects of lectins from Canavalia ensiformis and Canavalia brasiliensis in human leukemia cell lines. Toxicol In Vitro. 2012; 26(7): 1161-1169. doi:10.1016/j.tiv.2012.06.017

6. Liu, B., Li, C. Y., Bian, H. J., Min, M. W., Chen, L. F., Bao, J. K. Antiproliferative activity and apoptosis-inducing mechanism of Concanavalin A on human melanoma A375 cells. Arch Biochem Biophys. 2009; 482(1-2): 1-6. doi:10.1016/j.abb.2008.12.003

7. Ghazarian, H., Idoni, B., Oppenheimer, S. B. A glycobiology review: carbohydrates, lectins and implications in cancer therapeutics. Acta Histochemica. 2011; 113(3): 236-247. doi:10.1016/j.acthis.2010.02.004

8. Ferlay, J., Colombet, M., Soerjomataram, I., Mathers, C., Parkin, D. M., Piñeros, M., et al., Estimating the global cancer incidence and mortality in 2018: GLOBOCAN sources and methods. Int J Cancer. 2019; 144(8): 19411953. doi:10.1002/ijc.31937

9. Jones, D. B., Johns, O. C. Some proteins from the jack bean, Canavalia ensiformis. J Biol Chem. 1916; 28: 67-75.

10. Waterborg, J. H., Matthews, H. R. The Lowry method for protein quantitation. Methods Mol Biol. 1994; 32: 1-4. doi:10.1385/0-89603-062-8:1

11. Hankins, C. N., Kindinger, J. I., Shannon, L. M. Legume alpha-galactosidases which have hemagglutinin properties. Plant Physiol. 1980; 65(4): 618-622. doi:10.1104/pp.65.4.618

12. Mosmann, T. Rapid colorimetric assay for cellular growth and survival: application to proliferation and cytotoxicity 
assays. J Immunol Methods. 1983; 65(1-2): 55-63. doi:10.1016/0022-1759(83)90303-4

13. Liu, K., Liu, P. C., Liu, R., Wu, X. Dual AO/EB staining to detect apoptosis in osteosarcoma cells compared with flow cytometry. Med Sci Monit Basic Res. 2015; 21: 15-20. doi:10.12659/MSMBR.893327

14. Terho, P. Flowing software. Cell Imaging Core of the Turku Centre for Biotechnology, Turku, Finland 2012.

15. Chomczynski, P., Mackey, K. Short technical reports. Modification of the TRI Reagent ${ }^{\circledR}$ procedure for isolation of RNA from polysaccharide and proteoglycan rich sources. Biotechniques. 1995; 19: 942-945.

16. Livak, K. J., Schmittgen, T. D. Analysis of relative gene expression data using real-time quantitative PCR and the $2^{-\Delta \Delta \mathrm{Ct}}$ method. Methods. 2001; 25(4): 402-408. doi:10.1006/meth.2001.1262

17. Suvarna, G., Prabhu, A., Muhseena, N. K., Sharma, B. B. In vitro cytotoxic and apoptotic effect of concanavalins from Canavalia spp. on breast carcinoma cells. Int J Biol Sci. 2020; 11(1): 15-22.

18. Liu, X., Nie, H., Zhang, Y., Yao, Y., Maitikabili, A., Qu, Y., et al., Cell surface-specific N-glycan profiling in breast cancer. PLoS One. 2013; 8(8): e72704. doi: 10.1371/journal.pone.0072704

19. Roy, B., Pattanaik, A. K., Das, J., Bhutia, S. K., Behera, B., Singh, P., et al., Role of PI3K/Akt/mTOR and MEK/ERK pathway in Concanavalin A induced autophagy in HeLa cells. Chem Biol Interact. 2014; 210: 96-102. doi:10.1016/j.cbi.2014.01.003

20. Une, S., Nonaka, K., Akiyama, J. Lectin isolated from Japanese red sword beans (Canavalia gladiata) as a potential cancer chemopreventive agent. J Food Sci. 2018; 83(3): 837-843. doi:10.1111/1750-3841.14057

21. Wong, J. H., $\mathrm{Ng}, \mathrm{T}$. B. Isolation and characterization of a glucose/mannose/rhamnose-specific lectin from the knife bean Canavalia gladiata. Arch Biochem Biophys. 2005; 439(1): 91-98. doi:10.1016/j.abb.2005.05.004

22. Kajstura, M., Halicka, H. D., Pryjma, J., Darzynkiewicz, Z. Discontinuous fragmentation of nuclear DNA during apoptosis revealed by discrete "sub-G," peaks on DNA content histograms. Cytometry A. 2007; 71(3): 125-31. doi: 10.1002/cyto.a.20357

23. Chappell, W. H., Steelman, L. S., Long, J. M., Kempf, R. C., Abrams, S. L., Franklin, R. A., et al., Ras/Raf/MEK/ERK and PI3K/PTEN/Akt/mTOR inhibitors: rationale and importance to inhibiting these pathways in human health. Oncotarget. 2011; 2(3): 135-164. doi:10.18632/oncotarget.240

24. Parrales, A., Iwakuma, T. Targeting oncogenic mutant p53 for cancer therapy. Front Oncol. 2015; 5: 288. doi:10.3389/fonc.2015.00288

25. Ruhul Amin, A. R. M., Rajib, K. P., Vijay, S. T., Munna, L. A. A Novel role for p73 in the regulation of Akt-Foxo1aBim signaling and apoptosis induced by the plant lectin, Concanavalin A. Cancer Res. 2007; 67: 5617-5621. doi:10.1158/0008-5472.CAN-07-0655

26. Wolin, I. A., Heinrich, I. A., Nascimento, A. P., Welter, P. G., Sosa, L. D., De Paul, A. L., et al., ConBr lectin modulates MAPKs and Akt pathways and triggers autophagic glioma cell death by a mechanism dependent upon caspase-8 activation. Biochimie. 2020; 180: 186-204. doi: 10.1016/j.biochi.2020.11.003 